\title{
NADA DIATONIK PADA GELAS KACA \\ TERKAIT TINGKAT PENCAPAIAN PERKEMBANGAN MOTORIK HALUS PADA ANAK USIA DINI
}

\author{
Rina Wulandari \\ PAUD FIP Universitas Negeri Yogyakarta \\ wulandaririna80@gmail.com
}

\begin{abstract}
Abstrak
Penelitian ini bertujuan untuk mendeskripsikan nada-nada diatonik yang terdapat pada berbagai macam gelas kaca. Penelitian ini menggunakan pendekatan deskriptif kualitatif. Hasil penelitian menunjukkan bahwa gelas kaca yang menghasilkan nada diatonik adalah karakter gelas yang menghasilkan nada diatonis adalah jenis gelas Pilsener Glass, Water glass, dan gelas anggur. Nada dihasilkan berdasarkan gelas yang berbahan cenderung tipis, yaitu $2 \mathrm{~mm}$. Gelas kaca dapat menghasilkan nada yang nyaring dan terukur secara diatonik yaitu dengan cara memukul yaitu pada posisi $1 / 3$ bagian atas dari gelas. Karakter gelas yang tidak menghasilkan nada diatonik adalah gelas yang ketebalan bibir gelas lebih dari $2 \mathrm{~mm}$ dan adanya tangkai pada tubuh gelas.

Implikasi penelitian ini diantaranya adalah: 1) tingkat tebal-tipis bahan pembuat gelas kaca mempengaruhi kualitas nada diatonik yang dihasilkan gelas. Gelas kaca berkualitas nada diatonik berbahan kaca yang digunakan cenderung tipis transparan sehingga dapat menghasilkan bunyi nyaring saat dipukul dan 2) pelaksanaan pembelajaran pada anak usia dini perlu memperhatikan tingkat keamanan penggunaan gelas kaca ini (rentan pecah) yang disarankan untuk anak mulai usia 4 tahun.
\end{abstract}

Kata kunci: nada, diatonik, gelas kaca, motorik halus

This study aimed to describe the diatonic tones contained in a wide variety of glass beaker. This study used a qualitative descriptive approach. The results showed that the glass beaker that generates tones are diatonic character of glass that produces a tone diatonic Pilsener Glass is a type of glass, Water glass, and a glass of wine. The tone produced by glass made from thin inclined, that is $2 \mathrm{~mm}$. Glass cup can produce a loud tone and diatonic measured by way of hitting is the third position of the top of the glass. Character glasses that do not produce diatonic tone is the thickness of the glass rim of the glass more than $2 \mathrm{~mm}$ and the presence of a handle on the glass body.

The implications of this study are: 1) the level of thick-thin glass glass making materials affect the quality of the glass produced diatonic tones. Diatonic tone quality glass cup made of glass that are used tend to be thin transparent so as to produce a loud sound when struck, and 2) the implementation of learning in early childhood need to consider the level of security is the use of glass cups (vulnerable to rupture) is recommended for children from the age of 4 years.

Keywords : tone, diatonic, glass cups , fine motor skill

\section{PENDAHULUAN}

Estetika membahas tentang keindahan, yang tak bisa lepas dari perkembangan estetika dari masa ke masa. Anggapan rasa indah terhadap karya seni juga tidak dapat dilepaskan terhadap adanya bermacam aliran estetika. Seperti pendapat terdahulu bahwa periodisasi estetika di Barat (Eropa) adalah sebagai berikut, periode pertama dikenal sebagai estetika periode abad klasik yang lebih menekankan mimesis (imitasi) pada karya yang dihasilkan. Selanjutnya adalah estetika abad pertengahan yang lebih menekankan pada karya yang ditujukan untuk Tuhan yme, kemudian dilanjutkan pada estetika abad modern, serta sampai pada dengan abad postmodern yang 
menekankan pada ketidakberaturan dan anti kemapanan. Sejauh referensi yang peneliti kaji, Asia mempunyai ciri estetis yang berbeda dengan Eropa. Asia cenderung pada estetika timur yang menekankan pada makna dibalik penciptaan karya seni. Berbagai macam periodisasi estetika dapat dimungkinkan mewarnai pemikiran, anggapan dan hasil karya seorang seniman maupun apresiator.

Seni merupakan bagian dari estetika yang artinya adalah karya manusia yang mengandung keindahan. Seni terbagi menjadi beberapa macam, diantaranya adalah seni musik. Musik berhakekat yaitu bunyi sehingga pembelajaran ataupun aktivitas musik sudah seharusnya menyertakan bunyi. Lingkungan atau segala yang ada di sekitar anak tentunya dapat menghasilkan bunyi. Sebagai contoh: segala benda yang ada di sekitar anak yang dikenai pukulan/ dipukul. Bunyi yang dihasilkan dari benda yang dipukul sudah tentu ada yang terdengar nyaring dan tidak nyaring.

Musik dalam penelitian ini menggunakan sistem tangganada diatonik atau sistem tangganada Barat yang mempunyai beberapa unsur yaitu irama, melodi, harmoni, frasering, dan ekspresi. Unsur melodi merupakan salahsatu unsur musik yang lebih banyak membahas bunyi dengan tingkat tinggi-rendah yang berbeda-beda sehingga menghasilkan tinggi-rendah nada dalam system tangganada diatonik.

Melodi mempunyai beberapa jenis sistem tangganada, diantaranya adalah sistem tangganada diatonik yang terbagi menjadi diatonik mayor dan diatonik minor. Diatonik terkait dengan tangga (skala) nada musik yang tiap oktafnya bernada delapan (http://kbbi.web.id/diatonik). Oxford Advanced Learner's Dictionary dinyatakan bahwa diatonik adalah "...using only the notes of the appropriate major or minor scale..." (hanya menggunakan nada berskala mayor dan minor ). Berdasarkan beberapa kutipan tersebut maka dapat disimpulkan bahwa diatonik adalah tangga (skala) nada musik yang tiap oktafnya bernada delapan dan hanya menggunakan nada berskala mayor dan minor.

Berdasarkan kesimpulan di atas maka dapat diberikan contoh benda-benda dilingkungan sekitar kita yang mempunyai skala nada/ tangganada diatonik yaitu: 1) yang termasuk nada dari alat musik non vokal yaitu gitar (elektrik dan non elektrik), bass (elektrik dan non elektrik), piano (elektrik dan non elektrik), recorder, biola, dsb. 2) alat musik yang berasal dari tubuh manusia yaitu paling spesifik adalah vokal.

Sebagai pengantar permasalahan penelitian ini, peneliti mengambil contoh alat musik gitar yang mempunyai berbagai macam nada dengan tinggi-rendah yang berbeda yang berasal dari senar yang dimainkan dengan cara dipetik. Beberapa gelas kaca sebagai benda yang ada disekitar kita juga mempunyai tinggirendah nada yang berbeda. Inilah yang menjadikan hal unik yang peneliti jadikan fokus permasalahan. Pengumpulan data dalam penelitian ini menggunakan observasi dan dokumentasi. Keabsahan data menggunakan triangulasi teknik.

\section{PEMBAHASAN}

bunyi $\begin{array}{crr}\text { Nada adalah tinggi rendahnya } \\ \text { dalam }\end{array}$ karya $r$ musik (http://kbbi.web.id/nada). Nada adalah "The quality of a sound, especially the sound of a musical instrument or one produced by electronic equipment (http://www.oxfordlearnersdictionaries.co $\mathrm{m}$ /definition/english/tone 1\#tone 14 4)

(kualitas dari suatu suara atau bunyi, terutama suara alat musik atau salah satu yang dihasilkan oleh peralatan elektronik). Pono Banoe (2003: 292) menyatakan bahwa nada adalah suara yang mempunyai frekuensi tertentu dan dengan symbol tertentu.

Berdasarkan beberapa pendapat tersebut maka nada adalah kualitas bunyi/ suara yang mempunyai frekuensi tertentu sehingga mempunyai variasi tinggi-rendah. 
Terkait penelitian ini maka berbagai macam suara/ bunyi dari berbagai jenis gelas dideskripsikan dalam kategori pengertian ini sehingga diketahui jenis gelas yang termasuk bernada ataupun tidak.

Deskripsi nada pada gelas kaca menggunakan system diatonik. Oleh karena itu, sekiranya peneliti perlu menyampaikan sedikit sejarah singkat tentang tangganada diatonik, berikut salahsatu kutipannya:

Istilah diatonis pertamakali diambil dari bahasa Latin. Diatonicus yaitu nada-nada yang terdiri dari tujuh nada do, re, mi, fa, sol, la, si...Musik diatonis sudah menggunakan standarisasi dalam menentukan tinggi (pitch) digunakan sistem penalaan Equal temperament yaitu berjarak $1-1-$ $1 / 2-1-1-1-1 / 2$. Dengan contoh tersebut dibuktikan antara nada satu dengan memiliki jarak tertentu dan disepakati nada A memiliki 440 Heartz (http://wisnumintargo.dosen.isi-

ska.ac.id/2011/03/08/jurnal-ketegisi-surakarta-vol-8-no-1-mei-2008pengetahuan-ekspresi-karyamusik/.

Diatonik mempunyai pengertian diantaranya adalah terkait dengan tangga (skala) nada musik yang tiap oktafnya bernada delapan (http://kbbi.web.id/diatonik). Oxford Advanced Learner's Dictionary dinyatakan bahwa diatonik adalah "...using only the notes of the appropriate major or minor scale..." (hanya menggunakan nada berskala mayor dan minor ). Diatonic atau diatonik adalah "tangganada atau urutan nada yang mengandung jarak satuan (tonos) dan tengahan laras (semi tonos) baik tangganada mayor maupun minor" (Pono Banoe, 2003: 114).
Berdasarkan beberapa kutipan tersebut maka dapat disimpulkan bahwa diatonik adalah tangga (skala) nada musik yang tiap oktafnya bernada delapan $(\mathrm{do}=1$, $\mathrm{re}=2, \mathrm{mi}=3, \mathrm{fa}=4, \mathrm{sol}=5, \mathrm{la}=6, \mathrm{si}=7, \mathrm{do}=\mathrm{i})$ dan hanya menggunakan nada berskala mayor dan minor dengan jarak 1-1-1/2-1$1-1-1 / 2$. Terkait penelitian ini, maka tangganada diatonik yang telah ada, peneliti gunakan sebagai alat observasi pada bunyi tiap-tiap gelas.

"A container made of glass, used for dringking out of" (Oxford Advanced Learner's Dictionary), yang artinya wadah yang terbuat dari gelas kaca yang digunakan untuk minum). Kamus Besar Bahasa Indonesia (KBBI) mengartikan bahwa gelas adalah tabung untuk minum yang terbuat dari kaca. Berdasarkan dua pendapat ini maka pengertian gelas kaca adalah tabung untuk minum yang terbuat dari kaca. Terkait penelitian ini maka gelas kaca yang peneliti dapatkan di lapangan adalah yang lazim digunakan untuk minum, diantaranya gelas anggur, pilsener glass (gelas bentuk vas bunga), dan water glass (gelas untuk minum air putih), gelas kopi (coffee glass), dan espresso cup.

Penelitian ini dikaitkan dengan pendidikan anak usia dini sehingga peneliti lebih menekankan pada motorik halus karena memukul gelas dengan tingkat daya tenaga tertentu dan dengan tujuan tertentu merupakan bentuk nyata dari gerakan motorik halus. Permen 58 tahun 2009 terkait lingkup perkembangan motorik halus pada tingkat pencapaian perkembangan anak usia 4-6 tahun terdapat pernyataan diantaranya adalah mengkoordinasikan mata dan tangan untuk melakukan gerakan yang rumit, sedangkan pada usia 5-6 tahun terdapat pernyataan bahwa anak usia 5-6 tahun mampu menggunakan alat tulis dengan benar, menggunting sesuai dengan pola, dan menempel gambar dengan tepat.

Karakteristik anak usia 49-60 terkait motorik halus bulan adalah 1. Mampu menalikan tali sepatu, 2. Mampu memotong kertas 
mengikuti garis, 3. Mampu menalikan 10 manik-manik, 4. Mampu mengkopi gambar X, 5. Mampu membuka \& meletakkan jepitan baju menggunakan 1 tangan, 6. Mampu membangun kotak menjadi jembatan, 7 . Mampu menuangkan dari berbagai botol tanpa tumpah, 8. Mampu menulis namanya

Karakter anak usia 61-72 tahun terkait motorik halus yaitu 1.Mampu melipat kertas menjadi $1 / 2$ atau $1 / 4,2$. Mampu membuat jiplakkan gambar tangan, 3. Mampu menggambar bujur sangkar, lingkaran, persegi $4, \&$ segi tiga, 4. Mampu membuat potonganpotongan kertas, 5. Mampu menggun akan pensil warna secara tepat, 6 . Mampu membuat

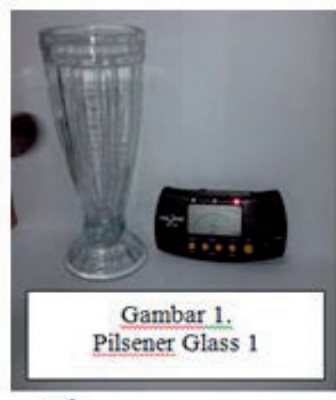

benda-benda kecil dari tanah liat, 7. Mampu menulis, 8. Mampu mengkopi 2 kata pendek(Sukadiyanto, http://staff.uny.ac.id/sites/default/fi les/Bahan $\% 20$ Ajar\%20PAUD $\% 20$ 1.\%20PENDIDIKAN\%20JASMA NI\%20ANAK $\% 20$ USIA $\% 20$ DINI .pdf) diakses 9 Oktober 2014.

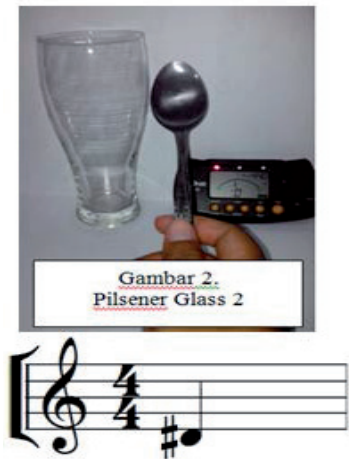
berpikir penelitian ini adalah keunikan gelas kaca yang menghasilkan bunyi nyaring yang mempunyai tinggirendah bunyi yang berbeda-beda.

Berbagai macam gelas yang peneliti dapatkan di lapangan mempunyai berbagai macam bentuk dan bunyiyang bermacam-macam. Artinya bahwa, tidak ada kesengajaan ataupun perlakuan terhadap karakter gelas. Begitu juga dengan alat pengukur nada. Alat pengukur nada juga telah ada di lapangan dalam berbagai macam format, penelitian ini menggunakan format alat digital. Adapun pertanyaan penelitian ini adalah: 1) bagaimanakah karakter gelas yang mempunyai kualitas nada diatonik?, 2) bagaimanakah karakter gelas yang tidak mempunyai kualitas nada diatonik?, 3) bagaimanakah mengetahui kualitas nada diatonik pada gelas kaca?, 4) nada apa saja yang terdapat di gelas kaca?, dan 5) bagaimanakah kaitannya dalam tingkat pencapaian perkembangan motorik halus anak usia dini?

Berdasarkan beberapa macam gelas yang peneliti dapatkan di lapangan, berikut deskripsi karakter gelas yang mempunyai nada diatonik:

Gambar 1 termasuk dalam jenis pilsener glass. Bentuk gelas menyerupai vas bunga (besar dan panjang) dan semakin ke bawah diameternya semakin mengecil. Diameter atas adalah $7,5 \mathrm{~cm}$, diameter bawah adalah $3 \mathrm{~cm}$, tinggi gelas yaitu $19 \mathrm{~cm}$ dan ketebalan bahan pembuat gelas adalah 2 $\mathrm{mm}$. Cara memukul gelas adalah pada posisi $1 / 3$ atas bagian gelas karena jika memukul pada bagian bawah maka tidak menghasilkan nada diatonik. Berdasarkan pengamatan yang peneliti lakukan, gelas pada gambar 1 mempunyai kualitas nada D\# (baca: D Kres).

Gambar 2 juga termasuk dalam jenis pilsener glass. Bentuk gelas menyerupai juga mirip vas bunga (besar dan panjang) dan semakin ke bawah diameternya semakin mengecil. Diameter bagian atas yaitu $7 \mathrm{~cm}$, diameter bagian bawah gelas yaitu $5,5 \mathrm{~cm}$, tinggi gelas adalah 16,5 cm, dan ketebalan gelas $2 \mathrm{~mm}$. Cara memukul gelas adalah pada posisi $1 / 3$ atas bagian gelas karena jika memukul pada bagian bawah maka tidak menghasilkan nada diatonik. Berdasarkan 
pengamatan yang peneliti lakukan, gelas pada gambar 2 mempunyai kualitas nada D\# (baca: D Kres).

Gambar 3 juga termasuk dalam jenis pilsener glass. Bentuknyapun juga menyerupai vas bunga (besar dan panjang) dan semakin ke bawah diameternya semakin mengecil. Diameter bagian atas yaitu $8 \mathrm{~cm}$, diameter bagian bawah gelas yaitu $6 \mathrm{~cm}$, tinggi gelas yaitu $16,5 \mathrm{~cm}$, dan tebal bahan gelas yaitu $2 \mathrm{~mm}$. Cara memukul gelas adalah pada posisi $1 / 3$ atas bagian gelas karena jika memukul pada bagian bawah maka tidak menghasilkan nada diatonik. Pengamatan yang peneliti lakukan, gelas pada gambar 3 mempunyai kualitas nada $\mathrm{C}$.

Gambar 4 juga termasuk jenis pilsener glass. Bentuk gelas menyerupai

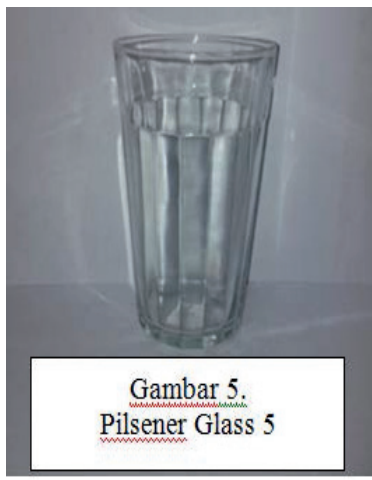
vas bunga (besar dan panjang) dan semakin ke bawah diameternya semakin mengecil. Diameter bagian atas gelas yaitu 7 $\mathrm{cm}$, diameter gelas bagian bawah yaitu $5,5 \mathrm{~cm}$, tinggi gelas yaitu $16 \mathrm{~cm}$, dan ketebalan bahan pembuat gelas yaitu $2,5 \mathrm{~mm}$. Berdasarkan pengamatan yang peneliti lakukan, gelas pada gambar 4 tidak dapat menghasilkan nada. Gelas ini mempunyai garis lurus ke atas pada sisisisi samping. Berat gelas ini melebihi gelas pilsener sejenisnya dan cenderung lebih tebal.

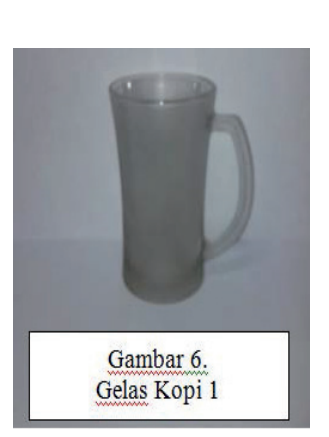

Gambar 5
termasuk gelas
pilsener karena bentuk
gelas menyerupai vas
bunga (besar dan
panjang) dan semakin
ke bawah diameternya
semakin mengecil.
Diameter bagian atas
gelas yaitu $7 \mathrm{~cm}$, diameter gelas bagian bawah yaitu $5,5 \mathrm{~cm}$, serta tinggi gelas yaitu $16 \mathrm{~cm}$. Berdasarkan pengamatan yang peneliti lakukan, gelas pada gambar 5 tidak dapat menghasilkan nada. Gelas ini cenderung tidak polos, lebih banyak variasi bentuk serta berat gelas melebihi gelas pilsener sejenisnya dan cenderung lebih tebal.

Gambar 6,7,8,9, dan 10 termasuk dalam jenis gelas kopi. Gambar 6 termasuk dalam jenis coffee cup/ gelas kopi. Gelas pada gambar 6 cenderung tidak bening/ tidak transparan, memiliki telinga/ tangkai, berbahan agak tebal. Bahan pembuat gelas yang cenderung tebal dimaksudkan untuk menahan panas sehingga pada umumnya banyak digunakan untuk tempat/ wadah minuman jenis kopi panas maupun the panas. Diameter bagian atas gelas ini adalah 7 $\mathrm{cm}$.

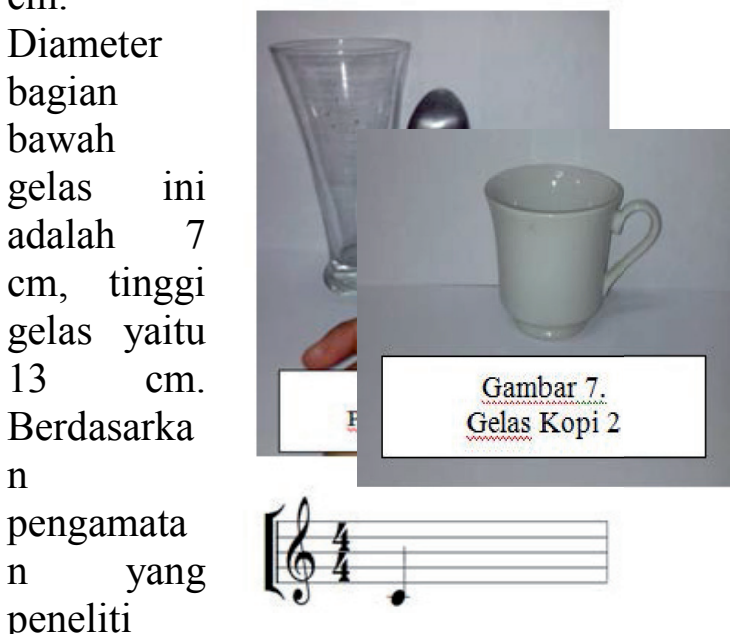
peneliti

lakukan, gelas pada gambar nomor 6 kurang ataupun bahkan tidak dapat menghasilkan kenyaringan bunyi yang dapat diukur menggunakan alat ukur nada.

Gambar 7 termasuk dalam jenis

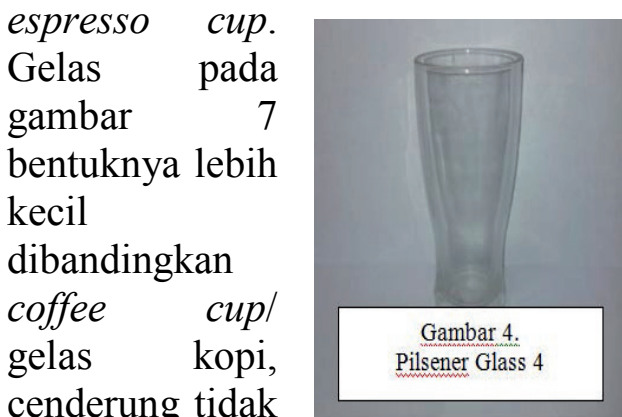

bening/ tidak transparan, memiliki telinga/ tangkai, dan berbahan agak tebal. Bahan pembuat gelas yang cenderung tebal dimaksudkan untuk menahan panas 
sehingga pada umumnya gelas espresso cup banyak digunakan untuk tempat/ wadah minuman jenis kopi panas maupun teh panas. Diameter bagian atas gelas ini adalah $8,5 \mathrm{~cm}$. Diameter bagian bawah gelas ini adalah $6,5 \mathrm{~cm}$, dan tinggi gelas yaitu 7,5 cm. Berdasarkan pengamatan yang peneliti lakukan, gelas pada gambar nomor 7 kurang ataupun bahkan tidak dapat menghasilkan kenyaringan bunyi yang dapat diukur menggunakan alat ukur nada.

Gambar 8 dan gambar 9 termasuk jenis coffee cup/gelas kopi. Gelas tersebut cenderung bening/ transparan, memiliki telinga/ tangkai, berbahan agak tebal. Bahan pembuat gelas yang cenderung tebal dimaksudkan untuk menahan panas sehingga pada umumnya banyak digunakan untuk tempat/ wadah minuman jenis kopi panas maupun teh panas. Diameter bagian atas gelas gambar 8

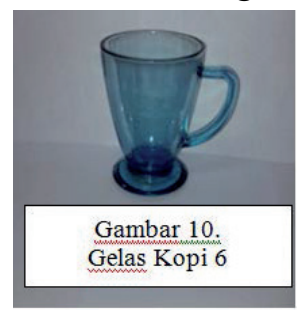
adalah $7,5 \quad \mathrm{~cm}$ sedangkan gambar 9 adalah $7,5 \quad \mathrm{~cm}$. Diameter bagian bawah gelas gambar 8 adalah 6 $\mathrm{cm}$ sedangkan gambar 9 adalah $6,5 \mathrm{~cm}$. Tinggi gelas gambar 8 yaitu $12,5 \mathrm{~cm}$ sedangkan gambar 9 adalah $12,5 \mathrm{~cm}$. Berdasarkan pengamatan yang peneliti lakukan, gelas pada gambar nomor 8 dan 9 kurang ataupun bahkan tidak dapat menghasilkan kenyaringan bunyi yang dapat diukur menggunakan alat ukur nada.

Gambar 10 termasuk dalam jenis espresso cup. Gelas pada gambar 10 bentuknya lebih kecil dibandingkan coffee cup/ gelas kopi, cenderung jenis gelas bening/ transparan, memiliki telinga/ tangkai, dan berbahan agak tebal. Bahan pembuat gelas yang cenderung tebal dimaksudkan untuk menahan panas sehingga pada umumnya gelas espresso cup banyak digunakan untuk tempat/ wadah minuman jenis kopi panas maupun teh panas. Diameter bagian atas gelas ini adalah 7,5 cm. Diameter bagian bawah gelas ini adalah $3,5 \mathrm{~cm}$ dan tinggi gelas gambar 10 yaitu 9,5

cm. Berdasarkan pengamatan yang peneliti lakukan, gelas pada gambar nomor 10 kurang ataupun bahkan tidak dapat menghasilkan

kenyaringan bunyi

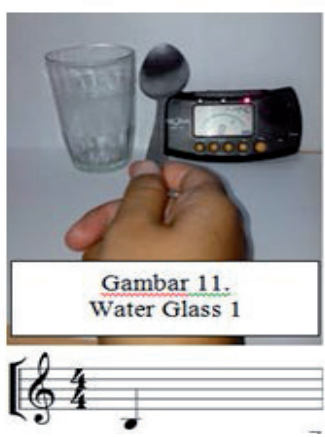
yang dapat diukur menggunakan alat ukur nada.

Gambar 11 termasuk dalam water glass. Bentuk gelas mempunyai deskripsi yang sama dengan gelas 11a, bentuk gelas biasa saja, tidak terlalu tebal, tidak memiliki tangkai atau telinga, namun kuat. Diameter bagian atas gelas yaitu $7 \mathrm{~cm}$ sedangkan diameter bagian bawah gelas yaitu $5 \mathrm{~cm}$, serta tinggi gelas adalah 9,5 cm. Berdasarkan pengamatan yang peneliti lakukan, gelas pada gambar 1 mempunyai kualitas nada B.

Gambar 11a termasuk dalam jenis water glass. Bentuk gelas biasa saja, tidak terlalu tebal (ketebalannya $2 \mathrm{~mm}$ ), tidak memiliki tangkai atau telinga, namun kuat.

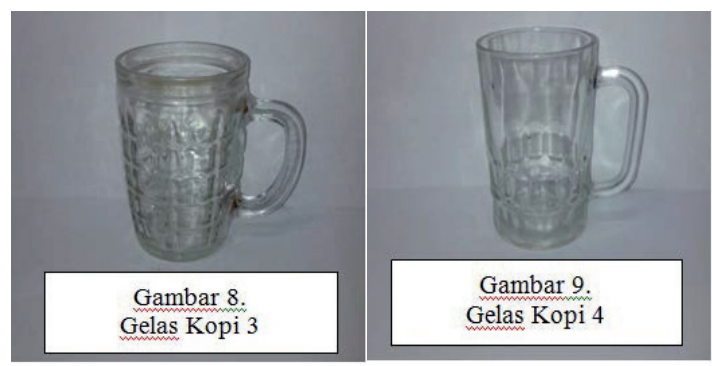

Diameter bagian atas gelas yaitu $7 \mathrm{~cm}$ sedangkan diameter bagian bawah gelas yaitu $5 \mathrm{~cm}$, serta tinggi gelas adalah $10 \mathrm{~cm}$. Berdasarkan pengamatan yang peneliti lakukan, gelas pada gambar 11a mempunyai kualitas nada C\# (baca: $\mathrm{C}$ Kres). 
Bentuk gelas pada gambar 12 termasuk dalam jenis gelas anggur yang cenderung berbentuk tulip, ramping atau memanjang, dan trasparan. http://007beritaterkini.blogspot.com/2012/ 05/jenis-jenis-gelas-yang-digunakanuntuk.html\#ixzz3E1XFkcg0. Tinggi gelas anggur ini adalah $11,5 \mathrm{~cm}$, diameter bagian atas gelas adalah $6 \mathrm{~cm}$, dan ketebalan $2 \mathrm{~mm}$. Berdasarkan pengamatan yang peneliti lakukan, gelas pada gambar 1 mempunyai kualitas nada E. Cara memukul gelas adalah pada posisi $1 / 3$ atas bagian gelas karena jika memukul pada bagian bawah maka tidak menghasilkan nada diatonik.

Gambar 13 termasuk dalam jenis gelas anggur. Gelas anggur cenderung berbentuk tulip, ramping atau memanjang, dan trasparan. Tinggi
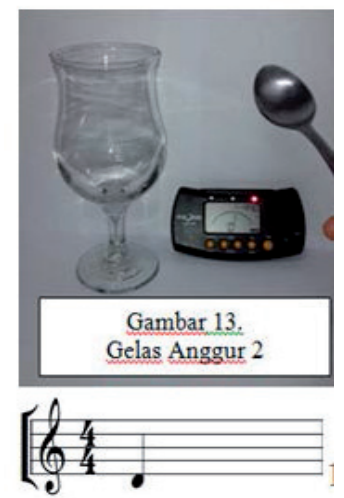
gelas anggur ini adalah 17,5 cm, diameter bagian atas gelas adalah $7,5 \mathrm{~cm}$, dan ketebalan bahan gelas adalah $2 \mathrm{~mm}$. Cara memukul gelas adalah pada posisi $1 / 3$ atas bagian gelas karena jika memukul pada bagian bawah maka tidak menghasilkan nada diatonik. Berdasarkan pengamatan yang peneliti lakukan, gelas pada gambar 1 mempunyai kualitas nada D.
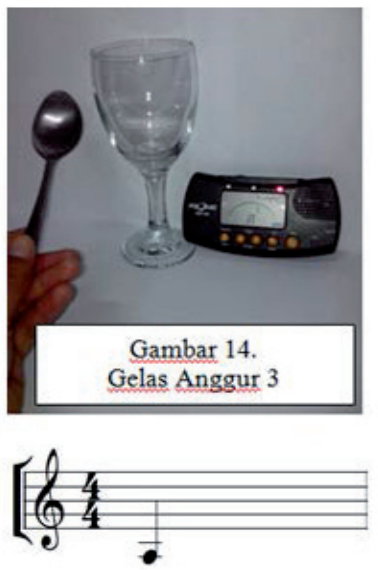

\begin{tabular}{lr}
\multicolumn{3}{r}{ Gambar } \\
$14 \quad$ termasuk \\
jenis & gelas \\
anggur. & Gelas \\
anggur & \\
cenderung & \\
berbentuk & tulip,
\end{tabular}

ramping atau memanjang, dan transparan. http://007beritaterkini.blogspot.com/2012/ 05/jenis-jenis-gelas-yang-digunakanuntuk.html\#ixzz3E1XFkcg0. Tinggi gelas anggur ini adalah $15 \mathrm{~cm}$, diameter bagian atas gelas adalah $6,5 \mathrm{~cm}$, ketebalan gelas yaitu $2 \mathrm{~mm}$. Cara memukul gelas adalah pada posisi $1 / 3$ atas bagian gelas karena jika memukul pada bagian bawah maka tidak menghasilkan nada diatonik. Berdasarkan pengamatan yang peneliti lakukan, gelas pada gambar 1 mempunyai kualitas nada A.

Hasil penelitian di atas telah menyebutkan berbagai macam jenis gelas beserta nada diatonik yang dihasilkan dan posisi dalam garis paranada. Terkait tingkat pencapaian perkembangan anak usia dini pada lingkup perkembangan motorik halus, maka hasil penelitian ini lebih terkondisi apabila dilakukan pada anak usia 4-5 tahun (anak kelompok A pada jenjang Taman Kanak-Kanak atau sejenisnya) dan 5-6 tahun (anak kelompok A pada jenjang Taman Kanak-Kanak atau sejenisnya). Hal ini disebabkan kemampuan anak usia 4-5 tahun dan 5-6 tahun terkait kontrol terkait cara memukul yang tidak menyebabkan gelas rusak/ pecah telah dimiliki. Mulai usia 4-5 tahun telah Nampak adanya kontrol dalam gerak motorik halus dan disusul kemudian pada kemampuan pada usia 5-6 tahun yang dengan jelas muncul ketepatan, kerapian, dan tingkat. Hal inilah yang kemudian peneliti jadikan dasar dalam membahas temuan penelitian ini.

\section{KESIMPULAN}

Berdasarka

$\mathrm{n}$ hasil penelitian dan pembahasan maka ditemukan bahwa:

1. Karakter gelas yang menghasilkan nada diatonis adalah jenis gelas Pilsener
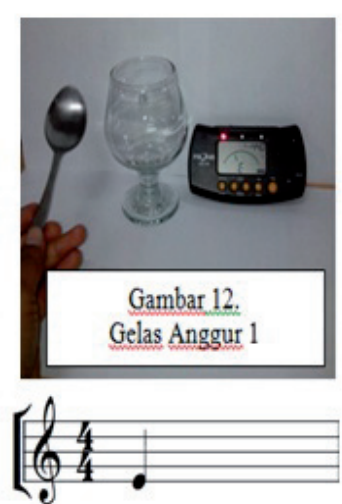
Glass, Water glass, dan gelas anggur. Nada dihasilkan berdasarkan gelas yang berbahan cenderung tipis, yaitu 2 $\mathrm{mm}$. Gelas kaca dapat menghasilkan nada yang nyaring dan terukur secara diatonik yaitu dengan cara memukul yaitu pada posisi $1 / 3$ bagian atas dari gelas.

2. Pilsener Glass yaitu gambar nomor 1 menghasilkan nada d', 2 menghasilkan nada d\#', dan 3 menghasilkan nada c'. Water glass yaitu gambar nomor 11 menghasilkan nada b dan 11a menghasilkan nada c\#. Gelas jenis gelas anggur yaitu gambar nomor 12 menghasilkan nada c', gambar nomor 13 menghasilkan nada d', dan 14 menghasilkan nada a'.

3. Gelas pada 4 termasuk dalam jenis pilsener glass, gelas pada 5 termasuk dalam jenis pilsener glass, gelas pada gambar nomor 6, 8, dan 9 yang termasuk dalam jenis coffe cup serta gambar nomor 7 dan 10 yang termasuk dalam espresso cup tidak mempunyai kualitas nada diatonik. Berdasarkan pengamatan, faktor ketebalan bibir gelasdan adanya tangkai gelas adalah penyebab tidak ditemukannya kualitas nada diatonik.

4. Menjawab pertanyaan ketiga yaitu "bagaimanakah mengetahui kualitas nada diatonik pada gelas kaca?", maka berikut langkah-langkah mendapatkan kualitas nada pada gelas kaca:

1) Siapkan gelas kaca yang akan diukur kualitas bunyinya.

2) Siapkan alat pemukul (penggaris, bahan logam lain).

3) Siapkan alat pengukur nada diatonik.

4) Gelas dipukul menggunakan alat pemukul pada bagian $1 / 3$ atas gelas sambil mendekatkan alat pengukur nada diatonik.

5. Menjawab pertanyaan kelima yaitu "bagaimanakah kaitannya dalam tingkat pencapaian perkembangan motorik halus anak usia dini?", maka berikut rinciannya, hasil penelitian ini lebih terkondisikan apabila dilakukan pada anak usia 4-5 tahun dan 5-6 tahun karena kemampuan motorik halus anak pada usia ini yaitu mampu kontroling terkait kemampuan motorik halusnya.

Implikasi dan saran penelitian ini diantaranya adalah: 1) tingkat tebal-tipis dan penggunaan tangkai/ telinga gelas kaca mempengaruhi kualitas nada diatonik yang dihasilkan gelas dan 2) pelaksanaan pembelajaran pada anak usia dini perlu memperhatikan tingkat keamanan penggunaan gelas kaca ini (rentan pecah). Khususnya untuk anak dibawah usia 4 tahun, resiko gelas rusak/ pecah lebih cenderung terjadi.

\section{DAFTAR PUSTAKA}

http://kbbi.web.id/diatonik)

http://www.oxfordlearnersdictionaries.com /definition/english/tone 1\#tone 1 4)

http://007beritaterkini.blogspot.com/2012/ 05/jenis-jenis-gelas-yang-

digunakan-

untuk.html\#ixzz3E1XFkcg0.

Diakses 3 Oktober 2014.

Pono, Banoe. 2003. Kamus Musik. Kanisius. Yogyakarta.

Sukadiyanto, Pendidikan Jasmani Anak Usia Dini.

http://staff.uny.ac.id/sites/default/fi les/Bahan $\% 20$ Ajar $\% 20$ PAUD $\% 20$ 1.\%20PENDIDIKAN\%20JASMA NI\%20ANAK $\% 20$ USIA $\% 20$ DINI. pdf) diakses 9 Oktober 2014.

Wisnu, Mintargo. 2008. Pengetahuan Ekspresi Karya Musik. Jurnal Kete'g ISI Surakarta.Vol. 8 No.1 Mei. Diakses 3 Oktober 2014. http://wisnu-mintargo.dosen.isiska.ac.id/2011/03/08/jurnal-ketegisi-surakarta-vol-8-no-1-mei-2008pengetahuan-ekspresi-karya-musik/ 